\title{
Augmented Feeding with By-passed Amino Acid and Slow-released Non- protein Nitrogen Supplement on Milk Peak, Lactation Persistency, and Post-partum Reproduction of Brazilian Buffaloes
}

\author{
Aquino DL, Del Rosario MV, Vergara KF, Cruz LC \\ Philippine Carabao Center, Central Luzon State University \\ Science City of Munoz, 3120 Nueva Ecija, Philippines \\ dalla_1358@yahoo.com
}

\begin{abstract}
Twenty five pregnant and primiparous Brazilian buffaloes were allotted in a Randomized Completed Block Design involving five dietary treatments namely; without $\left(T_{1}\right)$ or with $\left(T_{2}\right)$ augmented feeding plus supplementary by-passed amino acid (BPAA, $\mathrm{T}_{3}$ ); slow-released nonprotein nitrogen (SRNPN, $\mathrm{T}_{4}$ ) and its combination $\left(\mathrm{T}_{5}\right)$ to assess their milk peak, lactation persistency and post-partum reproductive performance. Five cows were assigned per treatment and each cow served as a replicate. The feed ration was composed of corn silage (67.3\%), rice straw $(9.5 \%)$ and dairy concentrate pellets (23.2\%). The supplementary concentrates, BPAA and SRNPN were given at $0.5 \mathrm{~kg} / \mathrm{kg}$ milk production, 100 grams and 50 grams $/ \mathrm{hd} /$ day, respectively. Results showed that augmented feeding alone or with supplementary BPAA and SRNPN gave significantly higher $(\mathrm{P}<0.05)$ peak milk of 12 and $12.5 \mathrm{~kg} / \mathrm{d}$, respectively. The milk peak was observed during $68\left(\mathrm{~T}_{1}\right)$ and 71 days $\left(\mathrm{T}_{5}\right)$ in milk of the cows. The dry matter and crude protein digestibility were significantly increased in $T_{2}$ and $T_{5}$. No significant differences were observed on lactation persistency but the observed value of $91.8 \%$ was closer to the reported ideal lactation persistency of $95 \%$ in dairy buffaloes. No significant differences were observed on the post-partum reproductive performance, feed intake, and the feed cost to produce a kilogram of milk. At 146 days service period using artificial insemination, $80 \%$ of the buffaloes were already confirmed pregnant. The use of augmented feeding with BPAA and SRNPN supplements gave a significant $(\mathrm{P}<0.05)$ net income of $\mathrm{P} 33,762.00$ (US\$ 720/cow) per lactation of the buffaloes.
\end{abstract}

Key Words: Augmented Feeding, By-passed Amino Acid, Slow-released Non-protein Nitrogen, Milk Peak, Brazilian Buffaloes

\section{INTRODUCTION}

The peak of milk production is an important indicator in developing appropriate nutrition for the dairy cows. Peak yield is achieved when the lactating cow reaches the highest production level during its entire lactation period. Normally, the cow exhibits milk peak at 45-90 days in milk (DIM), followed by the gradual decline in milk production over time until the animal completely dries-off (Anwar 2009). The milk yield and the average days to peak-milk are important parameters in assessing the lactation performance of the cows, Habib (2009). Report showed that for every kilogram increase in peak yield, a total forecast of 200 to 250 kilograms additional milk is expected per lactation period of the cow (Khols 2002).

There are four stages of lactation or groups of lactating cows to which the level of nutrition and the management practices are crucial. Level of dry mater intake depend on the level of milk production, which would be maintained by a range of nutrients intakes provided the intake of the other nutrient was adjusted to compensate for any change. For instan, cows in early lactation period required much higher levels of dietary protein than cows in mid lactation period (Cowan et al. 1981). 
During lactation, the peak of production is followed by the rate of decline in the milk yield of the cow which is also known as the lactation persistency. This is determined by dividing the current monthly milk production by the last month's milk yield of the cow and is expressed in a percentage unit. On the average, the reported persistency of lactation of a cow is about $94-96 \%$ (i.e. monthly milk yield is about $95 \%$ of the previous month), (Drackley 2002). After attaining the peak-milk, the milk yield drops by $0.2 \%$ /day during the first calving and about $0.3 \%$ decline per day in the succeeding lactations (Capuco et al. 2003). The importance of good nutrition and proper management practices are recognized especially during the transition period or at the peak of lactation of the cows.

Gradually, the appetite of the cow is increased during early stage of lactation to meet the nutrients required for milk production and for subsequent reproduction (Wood 1967). From mid to late lactation, the energy required for milk production is less because of the declining milk curve. Energy is still important especially for following pregnancy and the need of nutrients for body reserves. According to Moran (2005), it is more profitable to improve body condition of the cow in the late lactation when the efficiency of energy utilization is $75 \%$ rather than during the dry period when the energy efficiency is only $59 \%$.

In dairy animals, the efficiency of protein utilization for maintenance and for milk production is $60 \%$. In poultry and swine, however the dietary protein is efficiently utilized as high as $70-80 \%$, Satter \& Roffler (1977). Reports showed that in lactating cows, the Methionine (Met) and Lysine (Lys) are some of the limiting amino acids involved in microbial protein synthesis. This has been proven that the post-ruminal infusion of Met and Lys in dairy cows increased milk production, improved milk protein (3.15\% points) and milk fat (3.88\%) contents Socha et al. (1994). The increase in milk fat content was observed due to the enhanced de novo synthesis of short and medium-chain fatty acids in the mammary gland.

Reports showed that about $40-50 \%$ of the total protein requirement of ruminants is supplied in the form of microbial protein (Russell \& Strobel, 1989). The microbial protein supply for the animal is however; dependent on the turnover rates or the supply of nitrogen in the rumen. The cheapest source of nitrogen to enhance microbial protein synthesis is urea. The utilization of urea by the rumen microbes is dependent on the synchronicity or the supply of readily available energy source. To synchronize the utilization of NPN with energy source, a technique such as the encapsulation of NPN with fat or with other chelating compounds to slowly release the NPN source was found effective. The report of Nadeem et al. (2014) showed that slow release NPN as feed supplement to dairy buffaloes improves the milk production and fat content. This was due to the improvement in rumen the functions leading to increased fiber degradation and enhanced microbial protein turnover in buffaloes. Replacing the high protein diet with slow-release NPN source is considered a cost effective dietary supplement for dairy buffaloes.

In this study, the peak of lactation, lactation persistency and the subsequent reproduction of the dairy buffaloes were evaluated when the animals were subjected to challenge feeding with by-pass amino acids (BPAA) as source of rumen undegradable nitrogen (RUP) and the use of slow release NPN (SRNPN) supplement as source of rumen degradable protein (RDP) for enhancing the productivity of the animals.

Generally, the research aimed to improve the milk production and subsequent reproduction performance of dairy buffaloes through nutritional interventions i.e. to determine the peak-milk and persistency of lactation of dairy buffaloes when subjected to augmented feeding with BPAA and SRNPN supplements, to evaluate the nutrient utilization of dairy buffaloes when subjected to challenge feeding with supplementary BPAA and SRNPN sources, to assess if augmented feeding with supplementary BPAA and SRNPN can improve the post-partum reproductive performance of dairy buffaloes, to 
evaluate the effects of supplementary by-pass amino acids and slow release NPN source on the yield and quality of buffalo milk and to come-up with a simple cost analysis of the feeding interventions in dairy buffaloes.

\section{MATERIAL AND METHODS}

Twenty five pregnant and primiparous Brazilian buffaloes were allotted to five dietary treatments namely; without $\left(\mathrm{T}_{1}\right)$ or with $\left(\mathrm{T}_{2}\right)$ augmented feeding $(\mathrm{AF})$ plus supplementary by-passed amino acid (BPAA), ( $\left.\mathrm{T}_{3}\right)$; slow-released non-protein nitrogen (SRNPN), $\left(\mathrm{T}_{4}\right)$ and its combination ( $\left.\mathrm{T}_{5}\right)$. The cows on their last two months of pregnancy were assigned in a randomized complete block design with five cows per treatment and each cow serves as individual replicate.

\section{Feeding management}

The basal ration (Table 1) was composed of corn silage and rice straw. Concentrate supplement was given to the cows as per the requirement of each treatment. Supplementary molasses, mineral mix and salt were offered on top of their ration of the cows immediately after calving to the six months of lactation. All the cows were raised under complete confinement through-out the duration of the study.

Table1. The dietary rations used on as fed basis

\begin{tabular}{lccccc}
\hline \hline Item $(\mathrm{kg})$ & $\begin{array}{c}\text { Control } \\
\left(\mathrm{T}_{1}\right)\end{array}$ & $\begin{array}{c}\mathrm{AF} \\
\left(\mathrm{T}_{2}\right)\end{array}$ & $\begin{array}{c}\mathrm{AF}+\mathrm{BPAA} \\
\left(\mathrm{T}_{3}\right)\end{array}$ & $\begin{array}{c}\mathrm{AF}+\text { SRNPN } \\
\left(\mathrm{T}_{4}\right)\end{array}$ & $\begin{array}{c}\text { AF+ BPAA + SRNPN } \\
\left(\mathrm{T}_{5}\right)\end{array}$ \\
\hline Corn silage & 20.30 & 17.80 & 17.00 & 16.00 & 17.80 \\
Rice straw & 2.60 & 2.10 & 2.20 & 3.10 & 2.50 \\
Dairy conc pellets & 4.60 & 6.60 & 6.40 & 6.30 & 6.60 \\
BPAA & & & 0.10 & & 0.10 \\
SRNPN & & & & 0.05 & 0.05 \\
Mineral mix & 0.10 & 0.10 & 0.10 & 0.10 & 0.10 \\
Salt & 0.10 & 0.10 & 0.10 & 0.10 & 0.10 \\
Molasses & 0.90 & 0.90 & 0.90 & 0.90 & 0.90 \\
\hline Total & 28.60 & 27.60 & 26.80 & 26.55 & 28.15 \\
\hline
\end{tabular}

\section{Digestibility trial}

During the third month of the study, a digestibility trial was conducted involving three replicate cows from each treatment group. Before the digestibility trial, the replicate cows were first weighed to determine their live weights. A total fecal collection procedure for 24 hours was followed for five consecutive days. Collection of samples such as fecal samples, forage/feed offered and orts was done accordingly. The collected samples for five days were dried, grinded and were analyzed for its nutrient contents.

\section{Housing management}

All the cows were raised under complete confinement in an individual stall having a floor area of $18 \mathrm{~m}^{2}$. Each pen is equipped with concrete feed-bunk and automatic drinking 
trough. The cows were kept in their stall through-out the whole lactation period of 300 days. Cleaning and disinfection of the cows' pen were regularly done.

\section{Management of parturient cows}

Approximately one week before parturition, the body weight of the cows was determined using a digital balance. Veterinary assistance was provided to the cows during parturition. Immediately after calving, the calves were separated from their dams and a zero-suckling was practice in calf rearing. Other management practices such as hoof trimming and flashing of the uterus of the cows with iodine were done.

\section{Milking management}

The lactating cows were milked following the milking procedure developed by PCCGP farm. Milking was done twice a day using $2 \times 6$ tandem type e-Alpro milking machine. The morning milking starts at 4:00 AM and 3:00 PM for the afternoon milking. The daily milk production of the cows was recorded. Monthly milk samples were collected and analyzed for nutrient composition and somatic cell counts using milko-scan and somatic cell counter, respectively.

\section{Breeding management}

The cows were monitored for their reproductive performance such as post-partum estrus, service period and conception rate. Estrus observations followed by artificial insemination and pregnancy diagnosis of the cows were done by the assigned PCC-GP farm AI technician. If the cows did not conceive after three inseminations, these were subjected to natural mating by a cleaned-up bull.

\section{Health management}

The health management program developed by PCC was followed to maintain the healthy conditions of the cows. Vaccination against HS and Sura was employed. Ovarian palpation to determine the condition of the uterus, and the presence of cystic ovaries was also done by the farm AI technician. Monitoring of the incidence of mastitis using CMT and somatic cell analysis among cows was practice regularly at the farm.

\section{Data gathered}

1. Change in body weight, this was determined by monthly weighing of the dairy cows. The positive weight increase of the cows was expressed in total weight gained or ADG.

a. Feed/nutrient intake the daily feed consumption (as fed) of the animals is properly recorded. The nutrient intake is expressed on dry matter/day or DMI as percentage of the animals' live weight

b. DMI as \% body weight

c. Nutrients intake

2. Nutrient digestibility, the digestibility trial was conducted during the third month of the feeding trial. A 24 hour total fecal collection technique for five consecutive days was followed. Samples of feed offered, orts and feces were collected, dried and were grounded for laboratory analysis. The nutrients contents of the samples collected during 
the conduct of the digestibility trial were used in the calculation of the digestion coefficients for DM and crude protein.

3. Milk production and days in milk, the milk collected daily from each cow was recorded. This was expressed in daily and monthly milk production. The lactation period was expressed in days in milk.

4. Milk peak and persistency, the milk peak is reported as the highest daily milk yield produced by the cow in its entire lactation. The persistency of milk production is determined by dividing the current monthly milk production by the last month's milk yield of the cow and is expressed in a percentage unit.

5. Milk quality, this was determined by collecting the monthly milk samples from each cow and the collected milk were subjected to analysis using milko-scan and somatic cell counter equipment. Fat, lactose, protein, TS, SNF, and SCC.

6. Reproductive performance, this was done by close monitoring and recording the reproductive performance of the dairy cows before and after the parturition.

a. First post-partum estrus

b. Service period

c. Conception rate

7. Health parameters, the reproductive problem, mastitis, morbidity and mortality cases were monitored during the course of the study.

8. Cost analysis, the income derived from the augmented feeding with by-passed amino acid and slow released NPN supplements were calculated.

\section{Statistical design}

All the data gathered were analyzed using a randomized complete block design (RCBD). Significant observations among means shall be compared accordingly using duncan multiple range test (DMRT).

\section{RESULTS AND DISCUSSION}

\section{Changes in body weight of the cows}

The monthly body weights of the experimental animals were determined using a Rudd-weigh digital balance. Weighing of the animals started immediately after calving and continuously followed up to ten months of lactation. The data gathered on body weights showed that one week before the expected date of calving, the pregnant buffaloes had an average body weight of $510 \mathrm{~kg}$. After calving, the animals' average body weight was decreased to $477.9 \mathrm{~kg}$ or an equivalent weight loss of $32.1 \mathrm{~kg}$. The highest weight loss was observed in T4 (AF + SR-NPN) with $45 \mathrm{~kg}$ and the lowest loser in weight was in cows assigned to $\mathrm{T}_{5}(\mathrm{AF}+\mathrm{BPAA}+\mathrm{SRNPN})$ with $24 \mathrm{~kg}$ after calving. If the average weight loss of the dams is compared to the average birth weight $(34.5 \mathrm{~kg}$ ) of the calves born (Table 2), a difference of $2.4 \mathrm{~kg}$ in favor of the calves' birth weight.

The monthly weights of the cows, (Figure 1 and Table 2), showed an increasing trend of growth curves. This indicated that the primiparous cows have not attained yet their mature weight as evidenced by the increasing growth curve and ADG values. The highest ADG $(0.47 \mathrm{~kg})$ was observed in cows subjected to challenge feeding with supplementary BPAA and SR-NPN, ( $\mathrm{T}_{5}$ ) followed by the cows subjected to challenge feeding using supplementary dairy concentrate pellets with $0.45 \mathrm{~kg}$ ADG. Statistical analysis showed that the augmented feeding alone $\left(\mathrm{T}_{2}\right)$ or in combination with supplementary BPAA showed significant $(\mathrm{P}<0.05)$ results on $A D G$ when compared to $\mathrm{T}_{3}, \mathrm{~T}_{4}$ and with the lowest 
ADG recorded at $0.26 \mathrm{~kg}$ in the control group. The above significant findings further explained that the nutrients supplied to cows by $\mathrm{T}_{2}$ and $\mathrm{T}_{5}$ not only supply the requirements for growth but also the nutrients for milk production.

Table 2. Change in body weight of the dairy buffaloes as affected by dietary rations

\begin{tabular}{lcccc}
\hline \hline \multirow{2}{*}{ Treatment } & No. & BW before calving & BW after calving & Loss in BW \\
\cline { 3 - 5 } & & ------14.2 & 486.2 & $28.0^{\mathrm{a}}$ \\
\hline $\mathrm{T}_{1}$. Control & 5 & 514.2 & 472.2 & $37.2^{\mathrm{b}}$ \\
$\mathrm{T}_{2}$. AF & 5 & 509.4 & 479.2 & $26.4^{\mathrm{a}}$ \\
$\mathrm{T}_{3}$. AF + BPAA & 5 & 505.6 & 461.2 & $45.0^{\mathrm{c}}$ \\
$\mathrm{T}_{4}$. AF + SRNPN & 5 & 506.2 & 490.6 & $24.0^{\mathrm{a}}$ \\
$\mathrm{T}_{5}$. AF + BPAA + SRNPN & 5 & 514.6 & 477.9 & 32.1 \\
\hline Mean & & 510.0 &
\end{tabular}

Number with different superscript in the same coloumn significantly different in $\mathrm{P}<0.05$

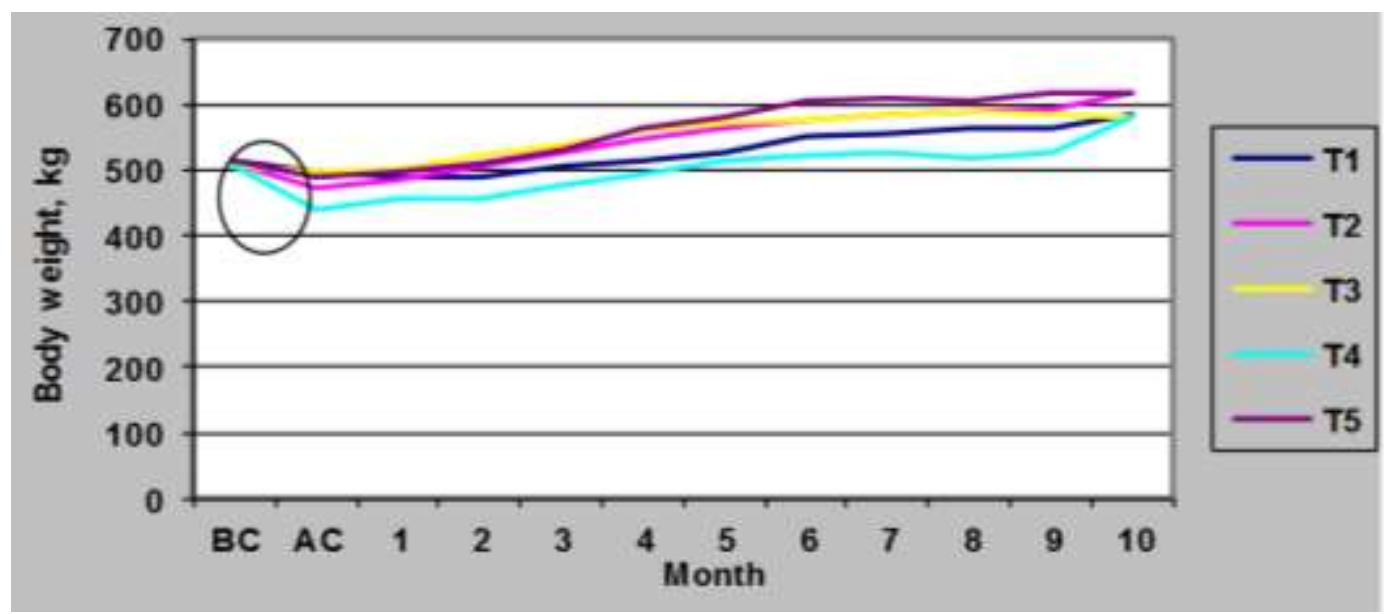

Figure 1. Monthly body weights of cows

\section{Feed intake and nutrient digestibility}

The data gathered on dry matter intake (DMI) as percentage of the body weight and the daily protein intake of the cows were not significantly affected by the either of the dietary treatments used in the study (Table 3). The highest DM (14.69) and CP (1.81 kg) intakes were observed in cows subjected to $\mathrm{AF}$ with supplementary combinations of BPAA and SRNPN while the control cows had the lowest DM and CP intakes of 13.59 and $1.56 \mathrm{~kg}$, respectively. The observed data on DMI as percent of the body weight though its not significantly different in all treatments are in agreement with the range of DMI as \% BW of lactating buffaloes published data by Kearl (1982), with the data ranges from 2$3.5 \%$ of the animals body weight.

As regards the calcium and phosphorus intake, the cows subjected to AF alone or with BPAA and/or SRNPN supplements had significantly higher $\mathrm{Ca}$ and $\mathrm{P}$ intakes than the control cows. In lactating cows, adequate levels of $\mathrm{Ca}$ and $\mathrm{P}$ in the ration is important because these macro-minerals are important in the synthesis of milk. The higher intakes of $\mathrm{Ca}$ and $\mathrm{P}$ by the cows primarily supplied by the concentrates and the mineral mix that had contributed to the significant increase in milk production specifically in cows assigned in $\mathrm{T}_{2}$ and $\mathrm{T}_{5}$. 
Table 3. The dietary rations used in the experiment

\begin{tabular}{lccccc}
\hline \hline Item & $\begin{array}{c}\text { Control } \\
\left(\mathrm{T}_{1}\right)\end{array}$ & $\begin{array}{c}\mathrm{AF} \\
\left(\mathrm{T}_{2}\right)\end{array}$ & $\begin{array}{c}\mathrm{AF}+\mathrm{BPAA} \\
\left(\mathrm{T}_{3}\right)\end{array}$ & $\begin{array}{c}\mathrm{AF}+\mathrm{SRNPN} \\
\left(\mathrm{T}_{4}\right)\end{array}$ & $\begin{array}{c}\mathrm{AF}+\mathrm{BPAA}+\text { SRNPN } \\
\left(\mathrm{T}_{5}\right)\end{array}$ \\
\hline Daily DMI (kg) & 13.59 & 14.33 & 13.89 & 14.43 & 14.69 \\
DMI as \% BW & 2.40 & 2.30 & 2.40 & 2.50 & 2.40 \\
Daily CP intake (kg) & 1.56 & 1.78 & 1.69 & 1.70 & 1.81 \\
Ca intake (g) & $101.00^{\mathrm{a}}$ & $129.00^{\mathrm{b}}$ & $118.00^{\mathrm{b}}$ & $118.00^{\mathrm{b}}$ & $129.00^{\mathrm{b}}$ \\
P intake (g) & $48.00^{\mathrm{a}}$ & $63.00^{\mathrm{b}}$ & $59.00^{\mathrm{b}}$ & $63.00^{\mathrm{b}}$ & $60.00^{\mathrm{b}}$ \\
DM digestibility (\%) & $66.64^{\mathrm{a}}$ & $68.48^{\mathrm{b}}$ & $67.01^{\mathrm{a}}$ & $68.24^{\mathrm{b}}$ & $69.50^{\mathrm{b}}$ \\
CP digestibility (\%) & $63.69^{\mathrm{a}}$ & $68.00^{\mathrm{b}}$ & $64.48^{\mathrm{a}}$ & $68.00^{\mathrm{b}}$ & $68.52^{\mathrm{b}}$ \\
\hline
\end{tabular}

Number with different superscript in the same row significantly different in $\mathrm{P}<0.05$

The results of the digestion trial showed that the lactating cows in $\mathrm{T}_{2}, \mathrm{~T}_{4}$, and $\mathrm{T}_{5}$ gave significantly higher DM digestibility coefficients of 68.48, 68.24, and 69.50\%, respectively compared to the cows in the control and the $\mathrm{T} 3$ ( $\mathrm{AF}+\mathrm{BPAA}$ ) groups. The observed digestibility values indicated that the DM contents of the corn silage, concentrates and rice straw which are the major components of the rations were significantly digested both by the microbes in the rumen and the host animals. The lowest DM digestibility was noted in the control group with $66.64 \%$.

\section{Milk production, composition and persistency of lactation}

The dairy buffaloes subjected to AF alone and AF + BPAA + SRNPN had the highest 305 days adjusted total milk yield of $1,433.2 \mathrm{~kg}$ and 1,586.4 $\mathrm{kg}$, respectively (Table 4 and Figure 2). These treatments had significantly higher $(\mathrm{P}<0.05)$ adjusted total milk production compared to the buffaloes in the control group $(1,120.9 \mathrm{~kg})$ and those cows subjected to $\mathrm{AF}+\mathrm{RNPN},(1,225.8 \mathrm{~kg})$ and $\mathrm{AF}+\mathrm{BPAA}(1,280.6 \mathrm{~kg})$.

Table 4. Effects of AF with BPAA and SRNPN on peak milk and lactation persistency

\begin{tabular}{lrrrrrrr}
\hline \hline \multirow{2}{*}{ Item } & \multicolumn{7}{c}{ Treatment } \\
\cline { 2 - 6 } & \multicolumn{1}{c}{$\mathrm{T}_{1}$} & \multicolumn{1}{c}{$\mathrm{T}_{2}$} & \multicolumn{1}{c}{$\mathrm{T}_{3}$} & \multicolumn{1}{c}{$\mathrm{T}_{4}$} & \multicolumn{1}{c}{$\mathrm{T}_{5}$} & Mean \\
\hline Peak-milk (kg/day) & $8.4^{\mathrm{a}}$ & $12.0^{\mathrm{c}}$ & $10.6^{\mathrm{b}}$ & $12.5^{\mathrm{c}}$ & $10.0^{\mathrm{b}}$ & 10.7 \\
Average peak-day & 78 & 68 & 89 & 66 & 71 & 74 \\
Adjusted 305 days milk yield (kg) & $1,120.9^{\mathrm{a}}$ & $1,433.2^{\mathrm{b}}$ & $1,280.6^{\mathrm{a}}$ & $1,225.8^{\mathrm{a}}$ & $1,586.4^{\mathrm{b}}$ & $1,329.4$ \\
Lactation persistency (\%) & 93.6 & 91.5 & 91.0 & 91.5 & 91.6 & 91.8 \\
\hline
\end{tabular}

Number with different superscript in the same row significantly different in $\mathrm{P}<0.05$

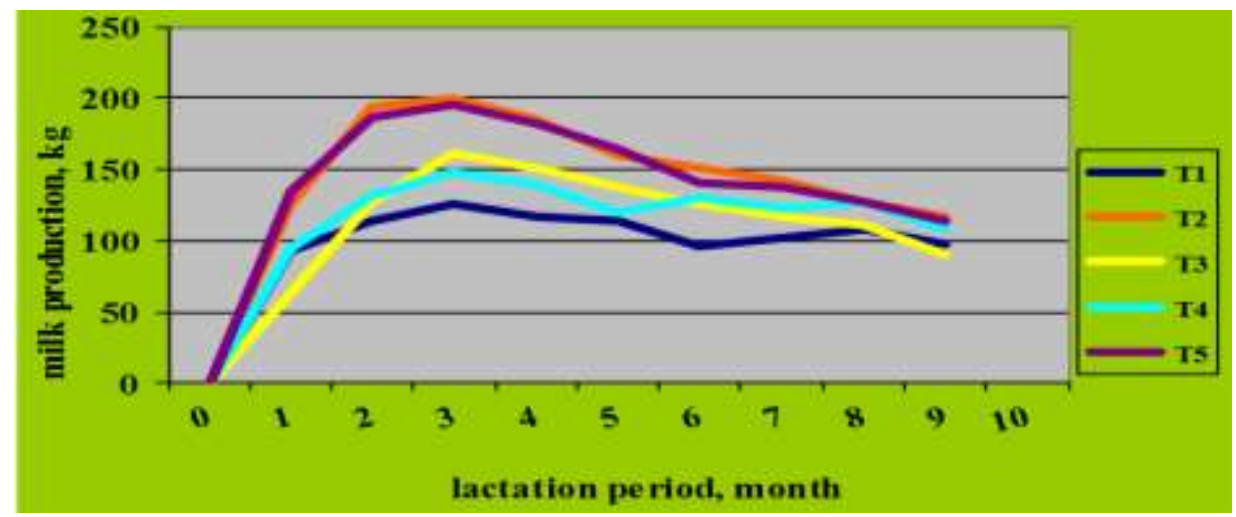

Figure 2. Milk production of buffaloes 
Buffaloes given AF plus SRNPN had the highest milk peak of $12.5 \mathrm{~kg} /$ day at 66 days in milk. No significant differences in milk peak were observed among the buffaloes assigned in AF alone, AF plus BPAA, SRNPN or its combinations. When these dietary treatments were compared with the control cows, these had significantly higher milk peak because the control cows had milk peak of only production $8 \mathrm{~kg} /$ day which was recorded at 78 days in milk. In this study, the average peak milk of the cows was observed on the 74 DIM (Figure 2). The observed value is consistent the report of Anwar (2009) that milk peak in buffaloes is exhibited during 45-90 days in milk.

In terms of persistency of lactation, there were no significant differences observed among the dairy buffaloes assigned in all the five dietary treatments. However, the observed lactation persistency of $92 \%$ was in agreement and was very close to the reported ideal lactation persistency of $95 \%$ in buffaloes (Drackley 2002).

On milk quality, the animals given challenge feeding with supplementary BPAA had significantly higher $(\mathrm{P}<0.05)$ milk fat $(9.72 \%)$ and total solids $(18.98 \%)$ contents compared to the rest of the treatments (Table 5). Milk protein, lactose and SNF were not significantly affected by the five dietary treatments including the milk produced by the control group. The highest somatic cell counts (SCC) of $151.8^{03} / \mathrm{ml}$ of milk was observed from buffaloes given AF + SRNPN. It can be noted that the SCC values $\left(200^{03} / \mathrm{ml}\right)$ gathered were acceptable and has passed the SCC standards for buffalo milk.

Table 5. Effects of AF with BPAA and SRNPN on milk composition of buffalo milk

\begin{tabular}{|c|c|c|c|c|c|c|}
\hline \multirow{2}{*}{ Treatment } & Fat & $\mathrm{CP}$ & Lactose & TS & SNF & \multirow{2}{*}{$\begin{array}{c}\text { SCC } \\
(000 / \mathrm{ml})\end{array}$} \\
\hline & \multicolumn{5}{|c|}{------------------- $\%$------------------ } & \\
\hline $\mathrm{T}_{1}$. Control & $7.04^{\mathrm{a}}$ & 4.33 & 4.63 & $16.15^{\mathrm{a}}$ & 8.99 & $52.18^{\mathrm{a}}$ \\
\hline $\mathrm{T}_{2} . \mathrm{AF}$ & $6.10^{\mathrm{a}}$ & 4.69 & 4.78 & $16.29^{\mathrm{a}}$ & 9.51 & $82.15^{\mathrm{ab}}$ \\
\hline $\mathrm{T}_{3} \cdot \mathrm{AF}+\mathrm{BPAA}$ & $9.72^{\mathrm{b}}$ & 5.00 & 4.36 & $18.98^{\mathrm{b}}$ & 9.20 & $91.01^{\mathrm{ab}}$ \\
\hline $\mathrm{T}_{4} \cdot \mathrm{AF}+\mathrm{SRNPN}$ & $6.79^{\mathrm{a}}$ & 4.41 & 4.34 & $15.63^{\mathrm{a}}$ & 8.84 & $151.83^{\mathrm{c}}$ \\
\hline $\mathrm{T}_{5} . \mathrm{AF}+\mathrm{BPAA}+\mathrm{SRNPN}$ & $7.34^{\mathrm{a}}$ & 4.70 & 4.65 & $16.34^{\mathrm{a}}$ & 9.24 & $70.36^{\mathrm{ab}}$ \\
\hline
\end{tabular}

Number with different superscript in the same coloumn significantly different in $\mathrm{P}<0.05$

\section{Reproduction data}

While the feeding trial is on-going, the lactating cows were monitored for their postparturient reproduction. Table 6 presents the data on service period, conception rate, number of services per conception and the cows with reproductive problems. The shortest services period was achieved by the cows subjected to challenge feeding with supplementary BPAA and SR-NPN with 106 days. The longest service period was observed in the control group with a service period of 167 days. In this study, the average service period (146 days) recorded was longer than the report of Alexiev (1998), in Bulgarian buffaloes which is from 90-122 days post-partum. The reason why longer service periods were gathered in the study because of the system used in estrus observation. The animals were kept in individual stall and the estrus observation was done by the assigned night-shift caretaker. Unlike in the breeding herds where the cows/heifers are raised in group, the observation is easy because of the use of a vasectomized bull which helps facilitate the observation of cows that are on estrus. Mounting behavior is one of the normal signs of estrus observed in the group of breeding herd but in this study mounting behavior is not possible since the cows were housed individually in their stall. 
There were no significant differences on the effects of AF plus BPAA and SRNPN supplements on the post-partum reproduction of the cows such as the service periods and conception rates $(\mathrm{P}>0.05)$. The earliest post-partum estrus of the experimental buffaloes was observed at 42 days, however; with an average of 146 days service period, $80 \%$ of the post-partum buffaloes were already confirmed pregnant through AI (Table 6).

Table 6. Effects of AF plus BPAA and SRNPN on the post-partum reproduction of buffaloes

\begin{tabular}{lccc}
\hline \hline Treatment & Service period (days) & Conception rate $(\%)$ & Number of S/C \\
\hline $\mathrm{T}_{1} \cdot$ Control & 167 & 80 & 1.50 \\
$\mathrm{~T}_{2} \cdot \mathrm{AF}$ & 142 & 80 & 2.00 \\
$\mathrm{~T}_{3} \cdot \mathrm{AF}+\mathrm{BPAA}$ & 161 & 80 & 2.30 \\
$\mathrm{~T}_{4} \cdot \mathrm{AF}+\mathrm{SR}-\mathrm{NPN}$ & 152 & 80 & 2.00 \\
$\mathrm{~T}_{5} \cdot \mathrm{AF}+\mathrm{BPAA}+\mathrm{SRNPN}$ & 106 & 80 & 2.25 \\
\hline Mean & 146 & 80 & 2.00 \\
\hline
\end{tabular}

\section{Effects of dietary treatments on animal health}

There were no major health problems observed during the feeding trial except for a recorded mortality when one healthy lactating cow in $T_{3}$ suffered from a heat stroke. This mortality, however; did not affect the monitoring of the peak of lactation because it happened on the seventh month of lactation. Another cow in $\mathrm{T}_{4}$ was found to have swollen ovaries due to the presence of cysts. Incidence of mastitis among the lactating buffaloes however, was not observed as evidenced by the lower somatic cell counts of the milk collected monthly from the experimental cows.

\section{Simple cost analysis}

Table 7 presents the revenues and the expenses incurred during the feeding trial. The data showed that $\mathrm{T}_{5}$ and $\mathrm{T}_{2}$ gave the highest revenues of Peso Philippines (PHP) 334.90 and 306.37/hd/day and these were significantly different compared to the revenues observed for the control, $\mathrm{T}_{3}$ and $\mathrm{T}_{4}$ with 225.8, 262.43 and PHP 250.80 hd/day, respectively. In terms of profitability, $\mathrm{T}_{5}$ and $\mathrm{T}_{2}$ gave the highest net profit of 33,762 and PHP 25,881/lactation, respectively. The cows subjected to AF supplemented with SRNPN had the lowest net profit of only PHP 9,540.00/lactation. 
Table 7. Simple cost analysis on the effect of AF with BPAA and SRNPN supplements on lactating buffaloes

\begin{tabular}{lrrrrr}
\hline \hline Item & $\begin{array}{c}\text { Control } \\
\left(\mathrm{T}_{1}\right)\end{array}$ & \multicolumn{1}{c}{$\begin{array}{c}\mathrm{AF} \\
\left(\mathrm{T}_{2}\right)\end{array}$} & $\begin{array}{c}\mathrm{AF}+\mathrm{BPAA} \\
\left(\mathrm{T}_{3}\right)\end{array}$ & $\begin{array}{c}\text { AF }+ \\
\text { SRNPN } \\
\left(\mathrm{T}_{4}\right)\end{array}$ & $\begin{array}{c}\text { AF + BPAA } \\
+ \text { SRNPN } \\
\left(\mathrm{T}_{5}\right)\end{array}$ \\
\hline Revenues & & & & & \\
Milk production & $1,120.90$ & $1,433.20$ & $1,280.60$ & $1,225.80$ & $1,586.40$ \\
Sales of milk (P/d) & 186.80 & 238.87 & 213.43 & 204.30 & 264.40 \\
ADG of cows & 0.26 & 0.45 & 0.32 & 0.31 & 0.47 \\
Equivalent value of ADG & 39.00 & 67.50 & 48.00 & 46.50 & 70.50 \\
(@PHP 150/kg lean) & & & & & \\
Gross revenue (P) & 225.80 & 306.37 & 262.43 & 250.80 & 334.90 \\
Expenses & & & & & \\
Feed cost & 142.67 & 174.35 & 159.31 & 173.35 & 176.70 \\
Labor cost & 24.24 & 24.24 & 24.24 & 24.24 & 24.24 \\
Biologics & 1.42 & 1.42 & 1.42 & 1.42 & 1.42 \\
Misc. & 20.00 & 20.00 & 20.00 & 20.00 & 20.00 \\
\hline Total expenses (PHP) & 188.33 & 220.10 & 205.00 & 219.01 & 222.36 \\
\hline Net revenue (PHP/hd/day) & 37.41 & 86.27 & 57.43 & 31.80 & 112.54 \\
\hline Net Income/lactation & 11,223 & 25,881 & 17,229 & 9,540 & 33,762 \\
(PHP/hd) & & & & & \\
\hline
\end{tabular}

\section{CONCLUSION}

The foregoing results of the study showed that augmented feeding alone or with BPAA and SRNPN supplements in dairy buffaloes came-out with the following conclusions: (1) Significantly higher ADG, 305 adjusted milk production and milk quality such as the milk fat, protein and total solid contents; (2) Significantly higher calcium and phosphorus intake, DM and protein digestibility and but not on the daily DM and protein intake; (3) Significantly higher net revenues PHP33,762 compared to the treatment groups; and (4) AF with or without BPAA and SRNPN supplements can be adopted by the farmers to increase the productivity of their buffaloes as well as their income in dairy farming.

\section{REFERENCES}

Alexiev A. 1998. The water buffalo. (Sofia) Bulgaria: St. Kliment Ohridski University Press.

Anwar M, Cain PJ, Rowinson P, Khan MS, Abdullah M, Babar ME. 2009. Factors affecting the shape of the lactation curve in Nili-Ravi Buffaloes in Pakistan. Pakistan J Zool. 9:201-207.

Capuco AV, Ellis SE, Hale SA, Long E, Erdman RA, Zhao X, Paape MJ. 2003. Lactation persistency: Insights from mammary cell proliferation studies. J Anim Sci. 81:18-31.

Drackley JK. 2002. Nutritional management for transition dairy cows. Urbana (US): Department of Animal Sciences, University of Illinois.

Habib G. 2009. Nutritional management strategies to improve milk production in buffaloes. Pakistan J Zool. 9:533-544. 
Cowan RT, Reid GW, Greenhalgh JFD, Tait CAG. 1981. Effects of feeding level in late pregnancy and dietary protein concentration during early lactation on food intake, milk yield, live weight change and nitrogen balance of cows. J Dairy Res. 48:201-212.

Kearl LC. 1982. Nutrient requirements of ruminants in developing countries. Logan (US): International Feedstuff Institute. Utah Agricultural Experiment Station. Utah State University.

Kohls D.2002. Feed and nutrition consultant form-a-feed. Minnesota (US): Form-A-Feed.

Moran J. 2005. Tropical dairy farming for small holder dairy farmers in the humid tropics. Clayton (AUS): Landlinks Press.

Nadeem SM, Pasha TM, Jabbar MA, Javed K, Khan MZ, Naveed S, Ditta YA. 2014. Effect of different non-protein nitrogen (NPN) sources on performance of lactating Nili-Ravi buffaloes. J Anim Plant Sci. 24:1-4.

Russell JB, Strobel HB. 1989. Effect of ionophores on ruminal fermentation. Appl Environ Microbiol. 55:1-6.

Satter LD, Roffler RR. 1977. Protein requirement and non-protein nitrogen utilization of ruminant. Trop Anim Prod. 2:31.

Socha MT. 1994. Determining the methionine requirements of lactating dairy cows [Thesis]. [Durham (US)]: University of New Hampshire.

Wood PDP. 1967. Algebraic model of the lactation curve in cattle. Nature. 216:164-165.

\section{DISCUSSION}

\section{Questions}

1. Why other contries still focus in buffalo, so many problems in buffalo, what is recomendation for each country why it profitable price?

2. How long is the calving interval of buffalo?

3. How farmer treat the calves produced?

\section{Answers}

1. Buffalo is unique in Philippines buffalo for meat and milk. Native buffalo for draught. Crossbreed the two buffaloes increase milk production. Carabao Center supported by Japan government. Milk processing can improve the carabao milk price.

2. The calving interval in farmer mostly 18-22 months, while in Carabao Centre is about 14-15 months.

3. The calves mostly are sale to the market after 3-4 months of age. 